\title{
THE IMAGE OF AUGUSTUS IN THE WORK OF SIDONIUS APOLLINARIS
}

\begin{abstract}
Summary: We found in the work in prose and verse of Sidonius Apollinaris (5th century) a few number of brief allusions to Augustus, and it comes to him in detail in the preface of Majorien's Panegyric (Poems IV) and, indirectly, in the dedicatory poem of the same Panegyric (Poems III). We here consider for what purpose Sidonius refers to Augustus, how he is presented, and what are the qualities that are highlighted. It appears that his relations with Virgil and Horace represent an ideal relationship between the poets and the power that Sidonius wants to give as an example.
\end{abstract}

Key words: Sidonius Apollinaris, panegyric, preface, Augustus, Maecenas, Virgil, Horace

A Gallo-Roman aristocrat who had an eventful life, closely linked to the history of the Roman Empire of the fifth century, Sidonius Apollinaris is the author of a collection of twenty-four Poems and nine books of Letters. ${ }^{1}$ Sidonius Apollinaris seldom mentions Augustus. He is briefly mentioned in the Panegyric to Anthemius when dealing with the tradition according to which he would be the son of Apollo who himself would have taken the shape of a snake when meeting his mother (Poems II 121-126). The Panegyric to Avitus shortly mentions the Actium victory over Anthony and Cleopatra (Poems VII 92-95). Augustus however takes an important part in the preface of the Panegyric to Majorian (Poems IV) and indirectly in the dedication poem of the same Panegyric (Poems III). If many recent articles have focused on the presence of myth in Sidonius Apollinaris, ${ }^{2}$ the presence of history in his work is far less

${ }^{1}$ The editions cited are: Sidoine Apollinaire, Poèmes. Texte établi et traduit par A. LOYEN. Paris, Les Belles Lettres 1961; Lettres. Texte établi et traduit par A. LOYEN. Paris, Les Belles Lettres 1970, 2 vol.

${ }^{2}$ FURBETTA, L.: Remarques sur la présence du mythe dans l'œuvre de Sidoine Apollinaire. Lalies 33 (2013) 275-290; Bruzzone, A.: Mito e politica nei Panegyrici di Sidonio Apollinare. In Gallien in Spätantike und Frühmittelalter. Kulturgeschichte einer Region. Hrsg. von S. DIEFENBACH - G. M. MÜLLER. Berlin 2013, 355-378. 
discussed. ${ }^{3}$ Nevertheless the interest of the dedication poem and preface of the Panegyric to Majorian did not escape Silvia Condorelli's ${ }^{4}$ or Severin Koster's ${ }^{5}$ attention. Renaud Alexandre ${ }^{6}$ and Geoffrey Todd Harrison ${ }^{7}$ also dedicated a few interesting pages to them. These introductory texts have the particular advantage to offer the poet more liberty whereas the panegyric itself is more exclusively dedicated to topical matters (which does not entirely exclude the expression of personal viewpoints).

Two specific details should be clarified beforehand. First of all, we must reassert that the dedication poem and the preface are not to be considered on the same plane as they do not have the same status. The preface is to be recited along with the Panegyric text whereas the dedication is to be regarded as a complementary element since it was written later for the published issue. This version was a partial edition, probably dating from $459 \mathrm{AD}$ and comprised the Panegyric and its preface along with the address to Petrus, that is to say Poems III-V of contemporary editions. Besides, the complexity of relationships between Sidonius and Majorian should be stressed as well as Sidonius's particular position. Avitus, a Gallo-Roman aristocrat from Auvergne who became emperor in 455, fell victim to a large coalition and was defeated in October 456 in Placentia by the combined forces of Majorian and Ricimer. Sidonius, who was Avitus's son in law, naturally found himself among the vanquished, regardless of his actual involvement in the battle. The Gallo-Roman aristocracy, outraged by the fate of the emperor, offered his diadem to Marcellinus, though Sidonius took no part in the conspiracy.

Majorian forcibly suppressed the revolt and the fall of Lyons in 458 was possibly the most violent episode of this period. The emperor himself then went to Lyons and Sidonius, who had negotiated the departure of the garrison from Lyons with Petrus, the emperor's trusted representative, delivered his Panegyric to Majorian on this occasion in December 458. More than an informative means, rhetoric, as we know, is used to influence people. Sidonius had actually several goals: convincing his unassured fellow countrymen to submit to the victorious authorities, inducing the emperor's clemency towards the culprits as well as his support to compensate the damages caused by the war, mainly in Lyons. Yet he was himself a Gallo-Roman and the son in law of Avitus ${ }^{8}$, a vanquished emperor. If he was shortly afterwards admitted in Majorian's inner circles and if the latter finally appeared to him as a liberal and

\footnotetext{
${ }^{3}$ See however GuILlaumin, J-Y.: Rappel de l'histoire et invitation à l'action dans les panégyriques de Sidoine Apollinaire. DHA Suppl. 8 (2013) 93-107, but he does not study this preface.

${ }^{4}$ Condorelli, S.: Il poeta doctus nel V secolo D.C. Aspetti della poetica di Sidonio Apollinare. Napoli 2008, 29-48.

${ }^{5}$ Koster, S.: Princeps und Poeta in Lyon (Sidon. carm. 3; 4; 13). In Festschrift für Paul Klopsch. Hrsg. von U. KINDERMANN - W. MAAZ - F. WAGNER. Göppingen 1988, $293-307$.

${ }^{6}$ AleXandre, R.: La voix du poète dans les Panégyriques de Sidoine Apollinaire. VL 180 (2009) 53-63.

${ }^{7}$ Harrison, G. T.: The verse Panegyrics of Sidonius Apollinaris: poetry and society in late antique Gaul. Ann Arbor 1983.

${ }^{8}$ Avitus's fate after his defeat is not clearly known, see LOYEN, A.: Recherches historiques sur les Panégyriques de Sidoine Apollinaire. Paris 1942, 59 n. 4. But he certainly died at the end of 456 or at the beginning of 457 .
} 
benevolent prince (see Letters I 11. 18 about an episode dated to 471 by André Loyen), Sidonius clearly did not know him when he recited his Panegyric and he then mainly perceived through him the triumphant power of the Roman Empire.

These elements being now clarified, let us now turn to our two poems. In the dedication poem of the Panegyric (Poems III), Sidonius chooses Petrus as a guide and judge of his poetical work, that is to say Majorian's magister epistolarum whom we mentioned and who acts for him as Maecenas did for Virgil who had dedicated his Georgics to him before writing the Aeneid (implicitly through Maecenas's influence). We shall omit the second part of the poem, influenced by Martial I $3,{ }^{9}$ which is an illustration of Sidonius's eclecticism in his literary inspirations. In any case, the comparison between Virgil and Sidonius, which is only implied here, is perfectly explicit in the following preface.

This preface (Poems IV) hinges on a double comparison. The poet develops an explicit identification between his own condition and that of the Virgilian Tityrus, seen as Virgil's alter ego himself. ${ }^{10}$ As Tityrus obtains from a deus, whom Sidonius directly regards as Augustus, the right to keep the property of his fields, similarly Sidonius, who had been confronted for some time to Caesar's wrath on account of his part in Avitus's military endeavours, eventually gains his pardon and the possibility to peacefully benefit his properties. Horace, the second figure of comparison, similarly obtained the forgiveness and poetical support from those he had previously fought.

The poem begins with a Virgilian quotation from Virgil's Eclogues I 1, Tityre $t u$, enriched by the anagrammatic transformation of $t u$ into $u t$, as Sidonius did not want to reproduce Virgil's lines literally. By reading Letters IX 14 (which deals with reversible lines), we realize how skilled Sidonius was in playing with letters.

Octavian's anger towards Brutus's followers subsided when confronted to humble Tityrus who then obtained the right to keep his land. In return, the apollonian gift (Phoebia dona, IV 17) of his Muse, humble as she was (rustica Musa, IV 6, referring to Eclogues III 84: Pollio amat nostram, quamuis est rustica, Musam), transformed the sovereign into a god (a hint to Eclogues I 6-10). Having recovered his land, the poet offered heaven (caelum pro terris rustica Musa dedit, IV 6), and that was a greater gift (nec fuit inferius Phoebeia dona referre: / fecerat hic dominum, fecit et ille deum, IV 7-8). Although Tityrus-Virgil was afflictus and a tenuis reus (IV 3 and 4), whereas Octavian was celsior (IV 4; the adjective bears on ira through hypallage), superiority was not on the expected side. The words nec inferius (IV 7) underline the inequality of the exchange between the poet and the prince.

Sidonius takes a distance from his Virgilian model in three ways. He asserts that Octavius grants Tityrus ius uitae et agri (IV 3). Now no line in the text of Virgil's first Eclogue says or even suggests that Tityrus received also the favour of keeping his life. Then, as we saw, Tityrus is described as tenuis reus, which was the object of Caesar's ira. Now, in the Vergils's Eclogues he is never shown as a defendant, nor is he subject to Octavian's anger; he only seeks protection against those who

\footnotetext{
${ }^{9}$ See CONDORELli (n. 4) 32-33.

${ }^{10}$ About the identification Tityrus-Virgil, attested since Servius, see CONDORELLI (n. 4) 35 n. 73.
} 
want to confiscate his lands. Sidonius acts as if Tityrus was on Brutus's side. In both cases, it seems that Sidonius changed Tityrus's position to make it similar to his own. Lastly, in Virgil's first Eclogue, Tityrus admits that deus nobis haec otia fecit (Eclogues I 6), whereas with Sidonius it is Tityrus-Virgil who makes a god of his benefactor through his verses. This inversion reveals the awareness of the fact that art is action and can therefore confer immortality on those it celebrates. ${ }^{11}$

If eight lines are dedicated to Virgil (IV 1-8), only two are dedicated to Horace (IV 9-10); for the sake of uariatio, Horace is addressed to in the second person (Et tibi, Flacce, IV 9). We do stress the parallel in the structure of Sidonius's line 3, in which Octavius grants Tityrus-Virgil ius uitae et agri, and that of line 10 in which he is carminis est auctor qui fuit et ueniae (with a hysteron-proteron) towards Horace. This parallel conceals a difference in consideration. Virgil's poetical creativity and talent are shown as existing prior to Octavius's intervention, whereas Octavius is the trigger (auctor) of inspiration with Horace. However, this is not strictly true: in Epistles II 2. 51-52, Horace says that after defeat at Philippi, it is poverty that led him to poetry (paupertas impulit audax / ut uersus facerem); and therefore, he began writing before he was introduced to Octavius. We cannot consider either that there is here an allusion to the pieces ordered by Octavius to Horace, it is to say the Secular Hymn, book IV of the Odes and Epistles II 1. ${ }^{12}$ Sidonius then probably wants to say more generally that Octavius gave him the possibility to write in material quietude.

Just as Virgil and Horace did, the present poet has enjoyed the emperor's forgiveness; Majorian not only forgave him but also ordered him not to feel vanquished (iussisti inuicto, uictor, ut essem animo, IV 12 , leonine verse with polyptoton; ${ }^{13}$ note the sudden use of the second person to refer to Majorian). The parallel between Virgil and Sidonius also could have been made easier by the geographical proximity of Placentia, where Avitus was defeated by Majorian, and Cremona, that was on Brutus's side.

In any case, the comparison with Virgil and Horace is significant: Sidonius indicates that the Panegyric whose preface constitutes this poem was rewarded by the preservation of his life (atque meae uitae laus tua sit pretium, IV 14). He was occasionally accused of being a fickle character, even if not a coward because he paid homage to an emperor who had defeated his father-in-law Avitus. In fact, he explicitly says that he has only paid a debt out of gratitude. Besides, he clearly expresses distances in his Panegyric to Majorian. In a short intermediate prooemium (V 370-373), he says that the first part of the poem was inspired by the vows of men (uota hominum docuere loqui, V, 371), and, as far as the second part is concerned, Mars will substitute for the Muses and Apollo (quae fanda mihi uel Apolline muto: pro Musis Mars uester erit, V 372-373). The absence of the Muses and Apollo in the Panegyric expresses the poet's reluctance towards the homage imposed on him (quae fanda mihi, V 372). He declares, in a rather indirect way, since direct expression was precluded,

${ }^{11}$ See CONDORELLi (n. 4) 38-39.

${ }^{12}$ See Suetonius's Vita Horatii. In C. Suetoni Tranquilli...reliquiae. Ed. A. REIFFERSCHEID. Lipsiae $1860,46,4$ sq.

${ }^{13}$ The text inuicto is however a correction, see CONDORELLI (n. 4) 45 n. 100. 
that it is his duty to speak, whatever his subject may inspire. We must take a closer look at the expression Mars uester. The possessive uester is generally understood as being related to Majorian, ${ }^{14}$ as if it were a plural of respect, and it is said to refer to his military feats. However such a usage is not documented in Sidonius. In fact uester refers to the group formed by Majorian, his staff and his collaborators. That is to say, the group in front of which Sidonius delivers his speech and from which he dissociates himself because he did not fight on their side, and because Mars, god of the Romans, does not suit the Gallo-Romans that well. More generally, Philip Rousseau has showed that the tone of the Panegyric to Majorian was not as enthusiastic as the Panegyric to Avitus and has demonstrated that the disillusion of the Gallo-Roman aristocrats as to their chances of ever controlling the imperial power could be felt in the text. $^{15}$

The poet's voice therefore serves him who saved his life (seruiat ergo tibi seruati lingua poetae, IV 13, with the paronomasia seruiat-seruati), and praises him through a poetical dedication that can be considered as apollonian, like that of Virgil. He now precisely bears the name of Sollius Apollinaris Sidonius and in several passages of the correspondence his name is associated with Apollo: in a poem inserted in a letter, he uses the conditional to call himself nouus Apollo (Letters VIII 9. 5, line 8); another letter teaches us that (Letters VIII 11.3) the orator Lampridius named Sidonius Phoebus, whereas Sidonius gave his friend the name of Orpheus; finally, a certain Philomathius implicitly passes jocular remarks on the name of Sidonius by associating Sollius with solus and Apollinaris with Apollo (Letters VIII 11. 3). ${ }^{16}$

The end of the poem hinges on a different point. If, compared to Virgil and Horace, whom Sidonius denies disparaging (we shall examine this point further below), his talent is minor (Sidonius specifies his panegyric poetry as tenue carmen in V, 593; he is dealing here with the locus humilitatis), his poem will appear all the more prestigious as the emperor he praises appears as major (IV 17): Res minor ingenio nobis, sed Caesare maior. Virgil and Horace prevail by their style but he prevails by the emperor he praises (uincant eloquio, dummodo nos domino, IV 18, in leonine verse). A similar touch was already to be found in the preface to the panegyric to Avitus (materia est maior, si mihi Musa minor, VI 36). Are such repetitions common routines with a panegyrist? Possibly; indeed, Sidonius reuses a number of passages and formulations from one panegyric to another (the evocation of the Roman emperors in VII 104-115 and V 317-327, for instance). But he could as well have repeated the expression in an effect of self-imitation to confer on it a new allusive sense. Indeed, the one he praises bears the name of Maiorianus, and is therefore greater. Sidonius does not clarify the play on words but the learned reader should nevertheless perceive it.

This poem is interesting in several respects. First of all, it is particularly elaborated (polyptoton, paranomasia, parallelisms, antithesis, etc.). There are two plays in

\footnotetext{
${ }^{14}$ So, implicitly at least with CONDORELLI (n. 4) 52-54.

${ }^{15}$ Rousseau, PH.: Sidonius and Majorian: the Censure in Carmen V. Historia 49.2 (2000) 251257.

${ }^{16}$ In Poems XIII 25-26, it is another part of Sidonius's name that is subjected to a play on the words: Sidonius is paralleled with the homonymous adjective, 'from Sidon'.
} 
particular on the proper nouns which are to be found here and there in the text without being clarified: the first bears on the name of Majorian; the second one makes a parallel between Apollinaris, which is one of Sidonius's three names, with the name of the god Apollo.

Thus Sidonius follows the highest literary tradition and assumes the attributes of Tityrus to express the relationship between the poets and the men of power. He compares himself with the two greatest Roman poets, Virgil and Horace. The first line of the poem, Tityre ut quondam patulae sub tegmine fagi (IV 1) has a programmatic value: Sidonius almost expresses himself as Virgil does. It is not the only passage in which Sidonius establishes a parallel with Tityrus's situation: it occurs in a passage of the correspondence, but in an inverted manner. In the poem inserted in the letter to the poet and rhetor Lampridius (Letters VIII 9. 5), Sidonius makes a comparison between Tityrus and Lampridius who leads a peaceful life in the country where he has returned under the protection of the visigothic king Euric and compares himself to Meliboeus who wastes his time waiting for the king to meet him. ${ }^{17}$ Virgil is thus a reference that enables him to render opposite situations. The poet of Mantua is central in the work of Sidonius, he is one of his literary models. ${ }^{18}$ As we saw, the distance with the Virgilian source is here particularly significant.

Lines 15-16 of our preface (non ego mordaci fodiam modo dente Maronem / nec ciuem carpam, terra Sabella, tuum) are a little surprising. Why does Sidonius need to insist so vigorously on the fact he is not attempting to depreciate Virgil or Horace? Is it for fear of being understood literally when he claims his superiority over them on account of the preeminent character of his subject? It is a leading rule with the writing of panegyrics to state that the present emperor prevails over the former ones, even if the fact is blatantly false. It seems that the atmosphere of suspicion, jealousy and hostility that prevailed at the court and in the inner circles of power had a strong impact on Sidonius who tried his best to elude it: the Arles satire affair (Letters I 11: Sidonius is wrongly accused of having composed a satirical pamphlet attacking prominent figures without designating them by name) but also other passages of the letters (Letters V 17. 5; and also III 13. 10-11; V 7; and Poems XII 22) show it well.

In poems III-IV Sidonius brings the Augustan golden age back to life. Maecenas is praised for his literary judgment (there is no hint to the protection he offered to poets); Octavian Augustus is praised for his clemency according to a tradition illustrated by Seneca's De clementia (I 9. 1 - I 11.2) and, on a different register, by Macrobius (Saturnalia II 4). Their contemporary equivalents are Petrus and Majorian.

${ }^{17}$ About this letter see Fo, A.: Sidonio nelle mani di Eurico (Ep. VIII 9). Spazi della tradizione culturale in un nuovo contesto romanobarbarico. In Memoria del passato, urgenza del futuro. Il mondo romano fra V e VII secolo. Atti delle VI giornate di studio sull' età romanobarbarica. A cura di M. Rotili. Napoli 1999, 17-37, a contribution that seems to have been developed in FO, A.: Arginare la decadenza da 'minore'. Sidonio Apollinare. In La decadenza. A cura di S. Ronchey. Palermo 2002, 154190 , which we were unfortunately unable to see.

${ }^{18}$ See Veremans, J.: La présence de Virgile dans l'œuvre de Sidoine Apollinaire, évêque de Clermont-Ferrand. In Aevum inter utrumque. Mélanges offerts à Gabriel Sanders. Steenbrugis - The Hague 1991, 491-502; Colton, R. E.: Some literary influences on Sidonius Apollinaris. Amsterdam 2000, 152; MAIR, J.: Some glimpses of Virgil in late antiquity. PVS 26 (2008) 32-40. 
Petrus's qualities are shown to equal Maecenas's. On the other hand the parallel between Augustus and Majorian is rather ambiguous since Majorian certainly forgives but he has also eliminated the legitimate ruler. This parallel therefore conceals a balanced judgment in favour of Augustus.

Finally, the modesty claimed by the author does not exclude his pride and the value he attributes to his own art. He compares himself to Virgil and Horace. Besides, if the poet grants immortality (as it is in any case asserted for Virgil), then he surpasses the emperor who can only spare life. Sidonius thus inverts his situation of debt and subordination towards Majorian. The primacy of poetry is clearly asserted. This emphasis also gives Sidonius the possibility to diminish the importance of his political role with Avitus.

To return to the original point, Augustus is, as a matter of fact, little present in these two introductory poems. He is however indirectly present through Maecenas, his minister, and through Virgil and Horace, the two major poets of his reign. The relationship he maintained with them is an ideal that Sidonius exemplifies as a model of relationships between poets and the governing power.

Étienne Wolff

Université Paris Ouest Nanterre

adda-wolff@wanadoo.fr

ewolff@u-paris10.fr 